\title{
PASANG SURUT GERAKAN FEMINISME
}

\author{
Saidul Amin \\ Dosen Fakultas Ushuluddin UIN Suska Riau; aminsaidul@yahoo.com
}

\begin{abstract}
A bstract: The Feminism Movement has played on important role in spreading the spirit of struggle for woman's right and freedom in the history of human civilization. However this movement also caused negative aspects on social life. That is the main idea of trying to put forward in this article, the fall and rise of feminism movement from the beginning unti lthe contemporary age.
\end{abstract}

Keywoods: Feminism movement, woman's right and freedom.,

A bstrak: Dalam sejarah peradaban manusia, gerakan feminisme memiliki peran yang sangat penting dalam menyerukan semangat untuk memperjuangkan hak-hak dan kebebasan perempuan. Namun gerakan ini juga pada akhirnya menimbulkan aspek negatif dalam kehidupan sosial. Inilah pokok pembicaraan yang akan dibicarakan dalam artikel ini, pasang surut gerakan feminisme dari awal sampai era kontemporer.

Kata K unci: Gerakan feminisme, Hak wanita dan kebebasan

\section{PEN DAHULUAN}

Feminisme pada dasarnya adalah pemikiran filsafat yang berupaya mengoreksi bias-bias pemarjinalan kaum perempuan dalam belantika kehidupan sosial. Walaupun muncul akibat pergolakan dan keluh kesah masyarakat barat, namun gelombangya tetap memengaruhi belahan dunia yang lain.

Gerakan ini mengalami pasang surut dan melahirkan aliran yang beragam dari mulai liberal, markis, sosialis, eksistensialis, radikal, psikoanalitik, postmodern, gender, global dan ecofeminisme. Setiap aliran walaupun berdiri di atas pondasi yang sama namun mendeklerasikan isu yang berbeda sesuai dengan kebutuhan zamannya. Pada akhirnya setiap zaman memberikan corak yang berbeda terhadap bangunan feminisme.

\section{PEMBAHASAN}

\section{Sejarah Lahirnya Gerakan Feminisme}

Zaman pencerahan atau enlightenment yang terjadi di Eropah pada abad ke 17 yang berperan sebagai tonggak sejarah penting dalam mendeklerasikan kebebasan dan kemajuan serta melepaskan diri dari kungkungan agama. ${ }^{1}$ Era ini disebut juga "the age of reason" yang mengkritik politik dan agama status quo. ${ }^{2}$ Enlightenment adalah kondisi dimana manusia menjadi subjek dan bebas menentukan jalan hidupnya.

Salah satu aspek terpenting didiskusikan di era ini adalah status perempuan yang sebelumnya dianggap sebagai makhluk setengah manusia yang hanya berperan sebagai pelengkap dalam sejarah manusia. Sehingga dari awal sejarah peradaban barat 
perempuan seringkali dipandang dari sudut negatif. Pada sisi lain bible juga berbicara tentang perempuan kaitannya dengan sejarah Hawa (Eva) sebagai sosok yang merayu Adam untuk berbuat dosa. Lalu literarur barat klasik sangat dipengaruhi oleh kisah dalam bible tersebut yang menimbulkan sikap anti terhadap feminis. ${ }^{3}$

Teologi Kristen yang dianutoleh mayoritas penduduk Barat seringkali dijadikan kambing hitam terhadap pemarjinalan perempuan dari laki-laki. Sosok Tuhan yang disebut dengan Father, bukan Mather. Sementara Yesus dipanggil sebagai the the Son of $\mathrm{God}^{4}$, bukan the daughter of God menimbulkan keyakinan bahwa Tuhan itu lelaki. Konsekwensi logis dari hal ini adalah bahwa lelaki memiliki sifat ketuhanan dan kedudukan lebih tinggi dari perempuan.

Kondisi inilah yang memengaruhi pemikiran masyarakat Barat pada saat itu yang melahirkan sikap meremehkan posisi wanita yang dianggap makhluk setengah manusia dan tidak punya hak-hak kemanusiaannya. Adalah Mary Wollstonecraft (1759-1797) yang dengan lantang menyerukan persamaan hak di antara lelaki dan perempuan serta menolak semua bentuk perbudakan. Dia juga sangat tajam mengkritik kebiasaan lelaki pada masa itu yang menjadi tirani terhadap keluarga. Pada sisi lain dia meminta perempuan untuk Iebih bersikap jantan dan lebih maskulin. ${ }^{5}$

Kemudian ide ini berkembang melintasi hamper seluruh belahan dunia dan mendapat tempat yang luar biasa di awal abad ke 20, khususnya di Amerika yang diprakarsai oleh Elizabeth Cady Stanton dan Susan B. A nthony. ${ }^{6}$

\section{Aliran-aliran dalam Gerakan Feminisme di Barat}

\section{Feminisme Liberal}

Feminisme liberal pada hakikatnya adalah sebuah perkembangan dalam filsafat feminisme yang didasari oleh mazhab kebebasan dalam pemikiran politik yang menekankan perlu adanya siakap rasional dan kebebasan manusia. Pada periode klasik, aliran ini menekankan bahwa lelaki dan perempuan sesungguhnya makhluk rasional, sehingga keduanya harus diberikan kesempatan yang sama berpartisipasi di bidang pendidikan dan politik. Kelompok ini menolak gambaran infirioritas yang selama ini ditampilkan oleh para filosof politik Barat. Di antara tokoh penting dalam periode ini adalah Mary Wollstonecraft (1759-1797), J.S.Mill (1806-1873), Harriet Taylor Mill (1807-1858), Elizabeth Stanton (1815-1902) dan lainnya.

Karya Mary Wollstonecraft tentang peningkatkan hak-hak perempuan dihargai sebagai sebagai karya perdana yang dipublikasikan aliran feminisme liberal. Inti dari karya tersebut adalah penolakan terhadap karya Rousseau "Emile", yang menyarankan pemisahan sistem pendidikan diantara lelaki dan peremapuan. Dia meneriakkan kesempatan yang sama bagi perempuan. Selanjutnya dia menekankan bahwa perempuan harus bebas dan merdeka dari semua bentuk penekanan lelaki dan mesti diberikan kesempatan dalam struktur sosiopolitik dan ekonomi dalam kehidupan umum. yang bukan hanya ingin menuntut hak-hak politik, namun ingin memerdekakan diri dari semua bentuk dominasi kaumlelaki dan bebas melakukan apa saja. ${ }^{7}$ 
A pabila Wollstonecraft lebih menekankan pemberdayaan perempuan di bidang pendidikan, maka J.S. Mill dan Hariet Taylor melangkah lebih jauh. Baginya pendidikan saja tidak cukup. Perempuan sebagai makhluk rasional harus sadar akan hak-hak sivil mereka dalam semua aktifitas kehidupan baik ekonomi, politik dan lainnya ${ }^{8}$. Kemudian Mill mempertanyakan kembali anggapan bahwa Ielaki lebih superior dibandingkan perempuan. Semua bentuk penindasan terhadap hakhak perempuan harus dihapuskan, sebab itu merupakan sisa-sia peninggalan zaman kuno.

Bukunya "the subjection of woman" merupakan rujukan terbaik di eranya yang ditulisoleh seorang lelaki dalam bidang feminisme. Mill memfokuskan pembicaraannya dalam tiga aspek penting dalam kehidupan perempuan yaitu, masyarakat dan pembangunan gender, pendidikan dan pernikahan.

Keduatokoh ini (J.S. Mill dan Hariet Taylor Mill) menyentuh permasalahan yang selama ini dianggap tabu oleh masyarakat Barat, yaitu perceraian. Keduanya sepakat perceraian harus dilegalkan. Namun keduanya berbeda dalam status anak paska perceraian. J.S.Mill menganggap ayah memiliki wewenang untuk membesarkan anak-anak. Sementara Taylor Mill justeru lebih cenderung kepada ibu dengan alasan psikologis, bahwa anak lebih dekat kepada ibunya.

Setelah periodeklasik, feminisme beranjak ke level modern yang diperakarsai oleh Betty Friedan (1921-2006) di dalam karyanya "Feminine Mystique" yang dianggap bukan sekedar karya yang sangat berpengaruh di dalam gerakan feminisme liberal modern, akan tetapi juga pintu gerbang yang membuka gelombang kedua gerakan feminisme di Amerika. Di dalam bukunya tersebut dia menggesa para perempuan untuk keluar dari "mistik" yangt beranggapan bahwa tugas perempuan sebagai isteri dan ibu adalah tugas mulia yang tidak pernah berakhir yang memberikan mereka kepuasan.

Dia juga berpendapat bahwa perempuan yang beranggapan tugas rumah sebagai pengabdiansuci abadi tidak dapatmeluangkan waktunya untuk aktifitas-aktifitas luar. Kegiatan shoping merekasesungguhnyahanya konpensasi dari rasasia-sia dan kesepian. Pada awalnyabuku "Feminine Mystique " ini menjadi buku best seller yang menginspirasi ratusan perempuan di Amerika untuk mencari kerja di luar. Namun pada akhirnya para perempuan menyadari bahwa kondisi seperti ini justeru membuat mereka mendapatkan dua beban kerja, di rumah dan di luar rumah.

\section{Feminisme Markis}

Kehadiran Feminisme Markis yang dilandasi oleh teori Engel yang beranggapan kemunduran perempuan terjadi disebabkan oleh kebebasan individual dan kapitalisme sehingga proverti itu hanya beredar di kalangantertentu, khususnyalelaki. Sementara perempuan justeru menjadi bahagian dari proverti tersebut. Untuk perempuan harus bangkit dan turut bekerja di sektor umum bersama lelaki. Intinya, kapitalisme adalah ancaman bagi kemerdekaan perempuan. ${ }^{9}$

Menurut Feminisme Markis, ciri-ciri pokok dari kekuatan dan kekuasaan di dalam keluarga dan masyarakat adalah ekonomi dan status lelaki. Pada awalnya sistem kemasyarakatan bercorak matriakat dan matrilineal dimana perempuan memiliki peran yang sangat penting dalam dalam produksi dan kehidupan material. Kemudian setelah aspek produksi berpindah dari rumah 
ke dunia luar, maka perempuan kehilangan posisi penting mereka.

Untuk itu perempuan secara ekonomi harus merdeka dari laki-laki dan hal ini adalah kunci kesetaraan hidup di antara dua jenis kelamin yang berbeda ini. Maka sistem kelas yang menjadi ciri dari masyarakat feudal harus dihapuskan, lalu menerapkan ide Marx yang menginginkan suatu masyarakat tanpa kelas, tanpa pembedaan gender.

\section{Feminisme Sosialis}

Ada pendapat menyatakan bahwa Feminisme Sosialis lahir sebagai kritik terhadap feminisme Marks yang selalu mengambinghitamkan kapitalis sebagai penyebab diskriminasi terhadap perempuan.

Bagi Feminisme Sosialis, permasalahan pemarjinalan perempuan sudah ada sebelum lahirnya teori kapitalisme. Untuk itu aliran ini berpendapat bahwa kebebasan dari ketergantungan ekonomi dari lelaki adalah syarat mutlak untuk kebebasan perempuan. Pernikahan yang merupakan persetujuan yang besar dalam hidup dan hubungan seksual di antara suami dan isteri sesungguhnya juga didasari oleh faktor ekonomi. Patriarchat dan kapitalisme merupakan penyebab utama penindasan perempuan. Tokoh penting dalam gerakan ini adalah Charlotte Perkins Gilman (1860-1935) dan Juliet Mitchell (1940-...).

Gilman di dalamkaryanya “ The Man-Made World and Woman and Economic" menjelaskan bahwa perempuan tidak akan pernah merdeka tanpa kemerdekaana ekonomi. Menurutnya juga, perempuan dipaksa untuk menikah juga karena faktor ekonomi. Pernikahan adalah kesepakatan hidup dan berkeluarga yang tidak tulus sebagai kurungan yang tidak alami yang hanya akan membuat kesedihan dan rasa frustasi.
Sementara Juliet Mitchel berpendapat bahwa empat struktur dalam masyarakat kapitalis yang meletakkan perempuan pada posisi yang rendah, yaitu: kedudukan perempuan dalam keluarga dan masyarakat, reproduksi, seksualitas dan bersosialisasi dengan anak-anak. Oleh sebab itu dia menegaskan bahwa kelompok feminis

harus menolak model produksi Kapitalis seperti halnya institusi keluarga di bawah sistem patriarchat yang mendudkkan wanita pada posisi yang rendah. Maka akhirnya kemompok ini memiliki selogan yang bagus, yaitu: “Tak Ada Sosialisme tanpa Pembebasan Perempuan. Tak A da Pembebasan Perempuan tanpa Sosialisme".

\section{Feminisme Eksistensialis}

Kelompok ini berargumen bahwa perempuan selalu diturunkan sebagai sosok kedua, tidak siknifikan dan posisinya tidak penting dibandingkan laki-laki. Pernikahan sesungguhnya telah merampas kebebasan wanita. Kemampuan mereka melahirkan dan mendidik anak adalah sumber dari penindasan. Bahkan pilihan hidup sebagai sorang isteri lebih hina dari seorang pelacur. Apabila pelacur mendapatkan bayaran dari setiap pelayanan yang mereka lakukan, maka bagi seorang isteri pelayanan hanya sekedar menjadikan mereka sebagai budak suami. Maka Tokoh gerakan ini De Beauvoir (19081986) menggesa para perempuan untuk aktif di dunia karir agar terhindar dari perangkap menjadi isteri dan ibu.

DeBeauvoirterkenal dengan ungkapannya “ On ne sait pas femme, on ledevient (One is nor born but rather becomes a woman). Pernyataan ini dianggap satu ungkapan yang paling radikal dalam sejarah teori feminisme ${ }^{10}$ bertujuan menolak tesis kelompok essentialisme yang 
menyatakan "women are born "feminine". Baginya tidak ada beda laki-laki dan perempuan. Akan tetapi kondisi sosial yang membuat perempuan itu menjadi perempuan. Ini yang diungkapkannya:

Woman is well placed to describe society, the world, the epoch to which she belongs,but only up to a certain point Truly greet works are thosethatput theworld entirely in question. Now that woman doesn't do. She will critique, she will contest in detail;but to put the world completely into question one must feel oneself to be profoundly responsible of the world. Now she isn't to the extent that it's a world of men; she doesn't take charge in the way the great artist does. She doesn't radically contestthe world, and this is why in the history of humanity there isn't a woman who hascreated a great religious or philosophical system, or even a truly great ideology; for that, what's necessary is in some sense to do away with everything that's given ("fairetable rase de tout le donne")-as Descartes did away with all knowledge-and to start afresh. Well, woman, by reason of her condition, isn't in a position to do that ${ }^{11}$.

Inti dari ungkapan di atas adalah kondisi perempuan yang tragis. Apabila manusia erat kaitannya dengan berfikir dan memberi definisi maka perempuan justeru berada pada posisi yang ragu dan dikeragui serta diberi definisi. Dengan kata lain perempuan adalah the others atau sesuatu yang lain. Dia bukan dirinya, tetapi tergantung orang mendifinisikannya. Dia hidup dalam dunia lelaki dan tergantung kepada belas kasihan mereka. Ini yang dikatakannya " She is defined and differentiated with reference to man and not he with referene to her, she is the incidental, the essential as opposed to the essential. He is the subject, he is the absolute-she is the other"12
Beavoir juga mengungkapkan tiga cara manusia mengeksistensikan dirinya, yaitu: being in self (Etre en soi), being for it self (Etre pour soi) dan Being for others (Etre pour les autres). Berkaitan dengan konsep yang ketiga, disinilah hakikat manusia sebagai makhluk yang senantiasa menjaga subjek dirinya dan menjadikan yang lain sebagai objek.

\section{Feminisme Radikal}

Aliran feminisme yang lain adalah feminisme radikal yang sudah ada sebelum tahun 1970. Kelompok ini sesungguhnya anti tesis dari dua kelompok sebelumnya, yaitu liberal dan marxis yang dianggap belum mampu memberi obat untuk menyelesaikan masalah di atas secara tuntas. Feminisme liberal beranggapan ada aspek yang menjadi akar penindasan lelaki terhadap perempuan. Pertama sistem patriarkis yang berlaku universal dimana Ielaki dijadikan sebagai pemimpin. Untuk itu sistem ini harus ditolak dan diganti. ${ }^{13}$ Penyebab kedua adalah kondisi biologis perempuan itu sendiri yang membuat dia lemah terhadap lelaki seperti haid dan melahirkan. Untuk itu perempuan harus menolak sistem patriarkis dan perempuan harus diberikan kebebasan untuk melahirkan atau tidak. Pelegalan aborsi dan melakukan pernikahan sejenis. ${ }^{14}$ Intinya aliran ini menjelaskan bahwa akar permasalahan ketidak adilan gender justeru terletak pada perbedaan seks reproduksi di antara lelaki dan perempuan. ${ }^{15}$

Perjuangan kelompok ini bukan tanpa hasil, sebab sampai Januari 2013 ini sudah ada sebelas negara di dunia yang melegalkan pernikahan sejenis, yaitu: Afrika Selatan, Argentina, Belanda, Belgia, Islandia, Kanada, N orwegia, Portugal, Spanyol dan Swedia ${ }^{16}$. 
Seperti diungkapkan di atas, menurut aliran ini, akar permasalahan perempuan adalah perbedaan reproduksi di antara lelaki dan perempuan. Mereka mengakui bahwa seks adalah permasalahan politik, kehamilan adalah budaya Barbar dan menjadi ibu merupakan akar dari semua kejahatan. Patriarcat menjadikan perempuan serba terbatas baik dari aspek seksual maupun reproduksi. Untuk itu diperlukan revolusi untuk menghapuskan keluarga biologis dan produksi biologis. Ini sesungguhnya dimungkin dengan mengembangkan kontrol reproduksi dan teknologi repreduksi, sehingga reproduksi itu menjadi lebih bebas dibandingkan dengan kebebasan ekonomi. Akan tetapi pada akhirnya kelompok ini terbelah menjadi dua friksi, yang pro terhadap penggunaaan teknologi reproduksi dan menolaknya. Ada beberapa tokoh penting dalam aliran ini di antaranya: Kate Millet (1934...), dan Shulamith Firestone (19452012).

Buku terpenting dalam aliran ini ditulis oleh Kate Millet berjudul "Sexual Politics" pada tahun 1970. Millet melakukan analisa sistematik tentang system sex/ gender dalam system Patriarkat. Menurutnya system ini menjadikan lelaki mendominasi aspek social dan politik kehidupan manusia termasuk permasalahan seks. Sebab itu hunbungan di antara lelaki dan perempuan sangat kuat. Pernikahan merupakan persekutuan financial dan keluarga adalah isntitusi tertinggi dari system patriarkat, dimana perempuan hanya berperan sebagai pelengkap. Untuk itu dia membela revolusi seksual dan promosi teknologi reproduksi untuk menawarkan kebebasan dan kemerdekaan perempuan dari ikatan pernikahan dan institusi keluarga.
Sementara filsafat feminisme Shulamith Firestone terhimpun di beberapa bukunya, di antaranya " The Dealectic of Sex ". Dalam buku ini dia menjelaskan bahwa reproduksi alamiahlah yang menyebabkan opresi terhadap perempuan.

Selanjutnya dia menyatakan bahwa setinggi apapun pendidikan dan status seorang perempuan selagi dia tidak bisa memerdekakan diri dari reproduksi alamiahnya, maka dia akan tidak pernah berubah. Untuk itu kemerdekaan perempuan harus dilakukan dalam satu revolusi biologis. Perempuan harus merdeka dari heteroseksual. Mereka bebas memilih untuk menjadi lesbian atau otoerotisme dan tidak perlu menjadi seorang ibu serta mengindari siklus empat $M$ yang selalu dilalui perempuan, yaitu: Menstruasi, Mengandung Melahirkan dan Menyusui.

\section{Feminisme Psikoanalitik}

Selain itu muncul pula aliran feminisme psikoanalitik yang melakukan interpretasi ulang terhadap konsep psikoanalisis Freud dari perspektif para feminist. Mereka menolak konsep "biological determinism" Freud yang selalu meletakkan posisi perempuan berada di bawah kontrol lelaki. Bagi Freud seks itu memang ada dua (lelaki dan perempuan) akan tetapi esensinya cuma satu saja, lelaki. ${ }^{17}$

Feminisme psikoanalitik menekankan bahwa" anatomyisnotdestiny". Kulturpatriarkat adalah akar permasalahan yang menentukan identitas perempuan dan menjadikannya pada posisi pasif, menderita dan narsis. Perasaan inferior dalam diri perempuan didasari oleh kultur dan interpretasi dari kultur biologi bukan biologi itu sendiri. Untuk itu transformasi psikologi perempuan mutlak untuk kemerdekaan perempuan. 
Menurut Karen Horney (1885-1952), rasa inferior perempuan bukan karena masalah anatomi dan pengalaman seksual, akan tetapi disebabkan oleh suborninasi sosial. Untuk itu perempuan harus melihat "feminity" sebagai adaptasi pertahanan terhadap patriarsi. Maka perempuan harus terbang meninggalkan keperempuanannya bukan untuk menjadi lelaki, akan tetapi membebaskan diri mereka dari kontrol laki-laki dalam masyarakat. Tokoh penting dalam aliran ini di antaranya adalah Alfred Adler (1870-1937), Clara Thomson (1893-1958) dan Juliet Mitchell (1940-...).

Adler berpendapat bahwa lelaki dan perempuan sesungguhnya dilahirkan dalam keadaan sama tidak berdaya. Permasalahan biologis tidaklah membuat perempuan berada padabumi inferior sementaralelaki padaranah superior. Kondisi tersebut sesungguhnya dibentuk oleh kondisi sosial masyarakat tersebut. Masyarakat yang patriarchal telah menyuguhkan satu dogma bahwa lelaki adalah pemimpin yang mengatur, menjaga dan memelihara perempuan, sehingga mengakibatkanperempuanmenderitaneorotik dan tidak bisa keluar dari cengkeramannya. Selagi system patrialchal masih ada maka kondisi perempuan akan tetap seperti itu. ${ }^{18}$

ClaraThomson tidak jauh berbeda dengan Adler yang menekankan kondisi social lebih memengaruhi sifat inferior perempuan terhadap lelaki ketimbang faktor biologis. Dengan kata lain interpretasi kebudayaan terhadap aspek biologis menghasilkan paradigma yang negatif terhadap hubungan Ielaki dan perempuan.

Mitchell walaupun sering dikategorikan sebagai tokoh dalam feminisme sosial namun dia juga banyak berperan dalam feminisme psikoanalitik, khususnya dalam buku "Psychoanalysis and Feminism" (1975), berintikan penolakan terhadap psikoanalisis Freud yang hanya berbicaratentang nafsu seks, sertahubungan lelaki dan perempuan. Mitchell menginginkan horizon yang lebih luas seperti peran perempuan dalam masyarakat dan dunia ${ }^{19}$. Artinya dia mengalihkan feminisme dari area genital menuju ranah global. Gagasannya tentang "Women is the longest revolution" " menjelaskan bahwa feminisme tidak bisa hanya dilihat dari penampilan luar namun apa yang ada di dalam "mind". Kelompok feminis tidak identik dengan yang berselendang atau bersarung. Feminis adalah apa yang ada dalam gagasan-gagasannya.

\section{Feminisme Postmodern}

Setelah itu muncul pula aliran Feminisme Postmodern yang berjal an di antaraFemi nisme Liberal dan Feminism Radikal. Inti dari feminisme ini adalah penolakan dikotomi di antara identitas lelaki dan perempuan. Bagi kelompok ini pengetahuan tentang lelaki dan perempuan sesungguhnya berada pada dataran tekstual. Oleh sebab itu perlu ada dekonstruksi teks-teks bias gender. ${ }^{20}$

Walaupun inti dasar pemikirannya masih sama dengan kelompok feminism yang lain, namun kelompok ini menganggap termarjinalkannya posisi perempuan dibentuk oleh struktur narasi-narasi besar budaya yang dibangun oleh bahasa laki-laki, dimana perempuan dianggap tidak memiliki peran. Maka jalan keluar terbaik adalah merekonstruksi bahasa tersebut.

Menurut Derrida ada tiga aspek penting dalam feminism yang perlu dekonstruksi. Pertama, pemahaman mengenai esensi perempuan dapat dibongkar karena dianggap hanya sebagai "teks". Kedua, pembongkaran tersebut menghasilkan interpretasi berbeda 
dengan teks-teks yang ada. Pengalaman perempuan muncul, memperlihatkan perbedaan, bahkan menunjukkan bagaimana konstruksi nilai perempuan sama sekali tidak inferior. Ketiga, pembongkaran teks maskulin melahirkan teks-teks feminisme serta suara feminin yang akhirnya melahirkan representasi perempuan yang sepanjang sejarah telah diopresi pemikiran besar filsafat maskulin ${ }^{21}$.

\section{Feminisme Gender (Feminisme Neo Markis)}

Kemudian lahir pula feminisme gender yang menolak semua bentuk "patriarchal oppressive system". Secara umum aliran ini sejalan dengan feminism radikal yang berupaya menghapuskan reproduksi biologi dan keluarga biologi dan berpendapat bahwa pernikahan heteroseksual dan menjadi ibu adalah tindakan politik. Selanjutnya mereka menyatakan bahwa semua bentuk penyimpangan seksual seperti homoseksual, lesbian dan transeksual mesti diterima. Semua alat buatan reproduksi dan keluarga mesti dipromosikan. Kehidupan seks harus dipisahkan dari institusi pernikahan dan reproduksi. Maka kebebasan seksual dan aborsi adalah sesuatu yang wajar agar perempuan dapat menikmati kehidupan seks yang selamat. Tokoh-tokoh dalam aliran ini adalah Judith Butler (1956-... $)^{22}$

Judith Butler, lahir 24 Februari 1956, adalah Maxine Elliott professor di Jurusan the Rhetoric and Comparative Literature pada Universitas California. Dia meraih PhD dalam bidang filsafat dari Universitas Yale pada tahun 1984, dengan disertasi Subjects of Desire: Hegelian Reflections in Twentieth-Century France.

Bukunyayang menyedot perhatian adalah Gender Trouble (1990) yang mengenalkan "teori performativitas" untuk mengulas jender dan seksualitas: bahwa tidak ada identitas jender yang asli, semuanya dibentuk melalui ekspresi dan "pertunjukan" yang terus diulang hingga terbentuk "identitas jender". Jender dan seksualitas menurut Butler seperti drag contest, lomba kecantikan yang dilakukan oleh waria untuk membuktikan mereka adalah wanita yang sebenarnya.

Mengasosiasikan gender dengan drag, Butler ingin mengatakan bahwa semua gender adalah "jadian-jadian" yang menipu kita dengan menampakkan dirinya seolah dia yang "asli". Padahal tidak ada yang asli. Jender adalah ciptaan kita sendiri karena kita yang menuliskan dan memilihnya di setiap KTP dan dokumen kita.

\section{Feminisme Multikulturalisme dan Global}

Dari gerakan domestik, feminisme mulai merambah ranah global dan melahirkan aliran Feminisme Multikulturalisme dan Global. Seperti diungkapkan di atas, kelompok ini sudah tidak lagi berbicara permasalahan domestik satu negara dan satu kultur akan tetapi sudah merebak secara multi dan bersifat global.

Feminismemultikultural

menekankan adanya "perbedaan" dalam menangani permasalahan perempuan.

Munculnya teori feminisme multikultural ini karena disadari adanya kesalahan dalam melihat persoalan perempuan, yang mengatasinya dengan memberi kesamaan dalam solusinya. Mengutip pendapat Elizabeth Spelman bahwa kegagalan teori feminis tradisional adalah keinginan mereka untuk melihat adanya persamaan pada setiap perempuan. 
Feminisme ini juga menolak kebijakan negara-negara tertentu yang bisa berdampak pada pemarjinalan perempuan di negara lain. Artinya, dunia ini menjadi rumah global yang menghilangkan sekat-sekat pembatas negara, ras, dan agama. Kebijakan negara tertentu terhadap perempuan akan menjadi diskusi bersama. Ajaran agama terntu tentang perempuan juga dihidangkan di meja makan global untuk didiskusikan olehsiapasaja. Maka pada akhirnya aliran ini mendeklerasikan bahwa semua bentuk kebijakan negaraapapun di dunia ini yang merugikan perempuan di negara tersebut dan berdampak kenegara lain harus dihentikan. Akhirnya semua bentuk penjajahan harus dihentikan sebab berimbas terhadap kebahagiaan perempuan.

Pada sisi lain pendekatan multicultural harus dikedepankan sebab setiap bangsa memiliki kultur sendiri. Pemaksaan pendekatan satu kultur kepada kultur yang lain sesungguhnya adalah bentuk lain dari penjajahan. Pendekatan Barat tidak mungkin dipraktikkan secara utuh di dunia Timur, demikian pula sebaliknya.

\section{Eco-feminisme}

Aliran ini dianggap sebagai gerakan kontemporer dalam rangkaian gerbong feminisme yang memandang hubungan lelaki dan perempuan dalam bentuk kecenderungan manusia untuk mendominasi alam. Dalam hal ini perempuan yang selalu pada posisi terdominasi diposisikan sebagai bagian dari alam. Kerusakan alam sesungguhnya juga akan merusakkan semua struktur kehidupan, termasuk perempuan. Ecofeminisme berpendapatada hubungan yang erat di antara feminisme dan ekologi.

Ekofeminisme muncul karena ketidakpuasan akan arah perkembangan ekologi dunia yang semakin bobrok akibat eksploitasi yang membabibuta tanpa memikirkan kelestarian alam. Manusia memperlakukan bumi dan alam menjadi bagian asing dalam diri mereka, sekan mereka tidak menetap di alam ini. Bumi dianggap hidangan yang harus disantap hari ini, bukan lagi pusaka dan warisan yang akan dititipkan untuk anak-cucu.

Teori ini mempunyai konsep yang bertolak belakang dengan tiga teori feminisme modern seperti di atas. Teori-teori feminisme modern berasumsi bahwa individu adalah makhluk otonom yang lepas dari pengaruh lingkungannya dan berhak menentukan jalan hidupnya sendiri. Sedang teori ekofeminisme melihat individu secara lebih komprehensif, yaitu sebagai makhluk yang terikat dan berinteraksi dengan lingkungannya. ${ }^{23}$

\section{PENUTUP}

Demikianlah sejarah dan pasang surut gerakan feminisme yang tumbuh dan berkembang dari ide persamaan hak menuju kebebasan yang otonom dan kemandirian tanpa batas yang justeru menghilangkan identitas keperempuanan itu sendiri dan membentuk gender ketiga. Pada akhirnya isu ini bukan lagi isu domestik namun sudah berpijak di ranah global. Tidak lagi berbicara perempuan sebagai manusia, namun perempuan sebagai bagian dari alam semesta.

Diskusi filsafat feminisme akan terus bergulir, sebab sampai saat ini belum ada format yang baku dapat diterima semua pihak. Sesungguhnya peran agama dinantikan untuk menyelesaikan semua bengkalai yang tak kunjung sudah. Filsafat harus kembali ke pelukan ibunya, agama. Kalau buntu jalan di bumi, bukankah masih terlalu lebar jalan ke langit. 


\section{Endnotes:}

1 Dorinda Outram (1999), The Enlightenment, New York: Cambridge University Press, h. 4.

2 Roy Porter (1990), The Enlightenment, London: Macmillan Press Ltd, h. 2.

3 Katherine Usher Henderson dan Barbara F. McManus (1985), Half Humankind, Chicago: University of Illionois Press, h. 3-7.

4 Anne Sofie Roald (1998), 'Feminist Reinterpretation of Islamic Sources: M uslim Feminist Theology in the Light of the Christian Tradition of Feminist Thought', di dalam Karin Ask dan Marit Tjomsland (ed.), Woman and Islamization: Contemporary Dimensions of Discourse on Gender Relations, Oxford: Berg

5 Sean Sayers dan Peter Osborne (1990), Socialism, Feminism and Philosophy: A Radical Philosophy Reader, London: Routledge, h. 24 25

6 Nancy F. Cott (1987), The G rounding of M odern Feminism, New York: Vail-Ballou, h. 13

7 Denise Thomson (2001), Radical Feminism Today, London: Sage Publication, h. 135

8 Marysia Zalewski (2000), Feminisn after Postmodernism: Theorising through practice, London: Routledge, h. 48

9 Elaine Storkey (1993), What's Right With Feminism, London: SPCK Holy Trinity Church, h 72-76.

10 M arysia Zalewski (2000), op.cit., h. 70.

11 Nancy Bauer (2001), Simone de Beauvoir, Philosophy \& Feminism, New York: ColombiaUniversity Press, 2001, hal. 52.

12 DeBeavior (1972), The Second Sex, Great Britain: Penguin Books, h. 16

13 Imelda Whelehan (1999), Modern Feminist Thought: From The Second Wave to PostFeminism, Edinburg: Edinburgh University Press, h. 70.

14 ElaineStorkey (1993), op.cit., h-94-99.

15 Janet A. Kourany et.al. (1993), Femininist Philosophies: Problem Theories and Aplication, New Jersey: Prentice Hall. Inc, h. 282.

16 www.merdeka.com/ gaya/ 11-negara yang melegal kan negara sejenis. Tanggal 2 Pebruari 2013
17 Michele Montrelay (1993), Inquiry into Femininity, di dalam Toril Moi (ed.), French Feminist Thought, Cambridge: Blackwell, h. 227.

18 JanePilcher dan Imelda Whelehan (2006), Fifty Key Concepts in Gender Studies, London: SA GE Publication, h. 123-124.

19 Ibid.

20 Ibid., h. 105-106.

21 http:/ / www.institutperempuan.or.id/ ?p=29.

22 Zeenath Kausar (2001), Feminist Sexual Politics and Family Deconstruction: An Islamic Perspective, Malaysia: IIUM Press, h. 19-20.

23 M egawangi, Ratna (1999). M embiarkan Berbeda: Sudut Pandang Baru tentang Relasi Gender. Bandung: Mizan. Cet. I, h. 1989.

\section{DAFTAR PUSTAKA}

A.Y. Collins (ed.), Feminist Perspectives on Biblical Scholarship, Chico, CA: Scholar Press

De Beavior, The Second Sex, Great Britain: Penguin Books, 1972

Denise Thomson, Radical Feminism Today, London: Sage Publication, 2001

Dorinda Outram, The Enlightenment, New York: Cambridge University Press, 1999

Eugene Thomas Long, Twentieth-Century Western Philosophy of Religion, Dordrecht,

Netherlands: Kluwer Academic Publisher, 2000

Elaine Storkey, What's Right With Feminism, London: SPCK Holy Trinity Church, 1993

Fakhr al-Razi, Tafsir al-Fakhr al-Razi, Beirut: Dar al-Fikr, 2005

Fatima Mernissi, Virginity and Fatriarchy", di dalam Azizah al-Hibri (ed.) Women and Islam,, Oxford: Pergamon Press, 1982

Hans-Georg Gadamer, Truth and Method, New York: Continuum, 1998 
Imelda Whelehan, Modern Feminist Thought: From The Second Wave to Post-Feminism, Edinburg: Edinburgh University Press, 1999

Jane Pilcher dan Imelda Whelehan, Fifty Key Concepts in Gender Studies, London: SAGE Publication, 2006.

Janet A. Kourany et.al., Femininist Philosophies:

Problem Theories and Aplication, N ew Jersey:

Prentice Hall. Inc, 1993

Katherine Usher Henderson dan Barbara

F. McManus, Half Humankind, Chicago: University of Illinois Press, 1985

MarysiaZal ewski,Feminisnafter Postmodernism:

Theorising through practice, London: Routledge, 2000

Mary Wollstonecraft, Vindication of the Right of Women, Harmondsworth: Penguin, 1978

Merry E. Wiesner-Hanks, Gender in History, Oxford: Blackwell Publisher, 2001

Nancy Bauer, Simone de Beauvoir, Philosophy $\mathcal{E}$ Feminism, New York: Colombia University Press, 2001
Nancy F. Cott, The Grounding of Modern Feminism, New York:YaleUniversity Press Natalie Zemon Davis dan Arlette Farge (eds), A History of Women: Renaissance and Enlightenment Paradoxes, London: Harvard University Press, 1993

Nietzsche, Beyond Good and Evil, London: Penguin, 1966

Olive Banks, Faces of Feminism, Oxford: Martin Robertson, 1981

Roy Porter, The Enlightenment, London: Macmillan Press Ltd, 1990

Sean Sayers dan Peter Osborne, Socialism, Feminism and Philosophy: A Radical Philosophy Reader, London: Routledge, 1990

Toril Moi (ed.), French Feminist Thought, Cambridge: Blackwell

----, Political Participation of Woman: Contemporary Perspective of Gender Feminists and Islamic Revivalists, Malaysia: Thinker's Library, 2008 